\title{
Generic Decision Support Model for Determining the Best Marketer
}

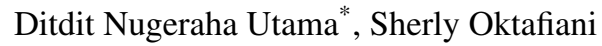

Computer Science Department, BINUS Graduate Program, Bina Nusantara University, Jakarta, 11480, Indonesia

A R T I C L E I N F O

Article history:

Received: 03 June, 2020

Accepted: 05 August, 2020

Online: 31 August, 2020

Keywords:

Marketer

Decision Support Model

Fuzzy Logic

Profile Matching
A B S T R A C T

For marketing company, determining the best marketing is a strategic decision. It is able to affect the companys future purposefully. The study conducted to propose a novel decision support model (DSM) for determining the best marketer. Seventeen parameters were considered into model and two methods fuzzy logic and profile-matching (PM) were combined as main method in constructing the model theoretically. The model was applied in medical appliance marketing company. It is finally also able to measure and present the best ranking of marketers that is able to make company for easily making a crucial decision.

\section{Introduction}

Today discussing department of marketing in a company cannot be ignored practically. Where the department is able to be compared to spearhead of the company, marketing itself has a very imperative function that is able to support the company's prosperity and profits [1]. Marketing allows interactions involving factors that provide attractiveness that are tailored to the company's strategy [2], as well as making a positive contribution through the process of developing long-term relationships through marketing interaction activities [3].

Thus, being able to give a stronger priority to marketing strategies and have positive implications for business [3], which are going to greatly affect the growth of a company. If the marketing performance is good, the company's growth will also be much better. When marketing increases business performance, a creative marketing strategy will be produced, to achieve the effectiveness of the implementation of corporate strategy [4]. Basically, a successful marketing department can be obtained by being success in supporting customers to buy back the products [5]. It can make customers become loyal customers [6].

Furthermore, the high level of competition in product marketing makes marketing department responsible in increasing sales value [7]. Marketing is a media that is very close to building business relationships to support companies. Helping companies in providing support and motivation to the marketing team to improve their ability to work is good effort to increase the company's income.

Based on technological developments, many ways have been taken by several companies to help or optimize marketing activities. Among other things, by implementing a decision support system (DSS) in e-tourism applications to help decide on the destination that best suits the interests of customers [8], the application of the Mehrabian-Rusel (MR) method to marketing DSS (MDSS) to examine weather factors in influencing consumer buying interest [7]. In addition, DSS is also combined with geographical information system (GIS) in marketing information systems as a tool for the decision making process to determine strategic locations to increase attractiveness for customers [9], and is also applied based on the concept of customer decision making (CDM) by using Model P6 for customers to determine web services that fit their needs [10].

In studies on the spread of advertising through social media, DSS has been successfully implemented too [11],[12]. But from a number of cases that help improve the quality of the company's business, there hasn't been any specific discussion in the marketing department itself. Because as we all know, marketing is an important point in improving the quality of a company's business [13]; then research on how to market to find out who is the best marketing person in a company through DSS is academically feasible to do.

Specifically for companies that distribute medical appliances in West Jakarta (Indonesia), which are the object of research, the company has difficulty in determining the ranking of marketers. This condition has an impact on the objectivity in determining the commission value of its marketers. This condition also, directly or indirectly, has an impact on the motivation of marketers' performance. Therefore, this research is carried out with the main

${ }^{*}$ Corresponding Author: Ditdit Nugeraha Utama, Computer Science Department, BINUS Graduate Program - Master of Computer Science, Bina Nusantara University, Jakarta, Indonesia 11480, +81289614291 \& ditdit.utama@ binus.edu 
objective to build a decision support model (DSM) that can determine objectively top-marketers.

Furthermore, DSM to determine the best marketers (topmarketers) is able to be used to provide incentives (bonuses) made already. This is a novel model to select the best marketer in specific pharmaceutical marketing company. Thus, the company is able to operate the best marketer suggested to next action, such as annual bonus giving. By considering seventeen selected-verified parameters and also applying a combination of fuzzy logic (FL) and profile matching (PM) methods, a constructed DSM is new scientific-proposed model. It is able to enrich a knowledge of computer science domain. Practically, it is able to become a new procedure to determine the best marketer specifically or employee commonly. The procedure is functioned to make the decision more objectively.

Moreover, for designing the model, object-oriented (OO) development method was functioned. This OO combined the data structure and behavior of all entities involved in the model through the abstraction of real world objects. $\mathrm{OO}$ was able to prove the efficiency for design modeling, and the implementation of a small scale object-based component information system involves segmentation steps [14]. Where the data analysis itself was carried out using data marketers at one of the medical distributor companies.

\section{Theoretical Framework}

\subsection{Fuzzy Logic (FL)}

FL was discovered by Prof. Lotfi Zadeh from the University of California at Barkeley in the mid-1960s, that the laws of right and wrong from Boolean logic did not take into account real conditions [15], Boolean reasoning itself conceptually related to unclear truth [16]. The main contribution of fuzzy logic is to provide a basis for the development from binarism to pluralism [17].

FL is part of artificial intelligence (AI) that is able to capture uncertainty or ambiguity into truth values. FL is used in assessing opinions based on human assumptions [18]. Fuzzy method itself is a classification and algorithm of ambiguity in the grouping of data [19]. Likewise what was said [20] that fuzzy can be used as a method in developing DSM based on gray and unexplained human language. The application of fuzzy methods is done because of its ability to capture uncertainty [21]. FL describes the variables that are the most unclear so that it can help in estimating reasons [22].

Compared to general methods that still provide subjective judgments in technical justification, through FL feelings of subjectivity can be avoided scientifically [23], where fuzzy-based models can provide realistic estimates [24]. Such as the application of fuzzy logic in predicting the location of mineralization that is known in the study area through complete and incomplete data [25]. The application of FL in considering different noise levels in a number of alpha planes and four types of membership functions in a comparison simulation to analyze the type-2 fuzzy approach when applied in fuzzy control [26]. Application of fuzzy sets in chaos control and chaos synchronization such as turbulence control, laser dynamics, plasma, chemical reactions, ecological systems and arrhythmias [27].
Then there is also the design of FL controller complexity with some rules embedded as energy management for microgrids that are connected to residential networks including renewable energy sources and storage capabilities [28]. In the proliferation of cellular devices and heterogeneous wireless communication environments in increasing the need for additional spectrum for data transmission is done by fuzzy-based decision making (FLB-DSS) which together deal with channel selection and channel switching to increase overall device throughput [29]. The selection of the right cluster head in reducing energy consumption dramatically through the fuzzy inference engine in choosing the opportunity that is most likely to overcome this [30]. The design of an index based on FL is aimed specifically at assessing the dynamic quality of agricultural land - Dynamic Quality Index (S-DQI) [31]. Overcoming the issue of merger and acquisition (M\&A) assessments and investors in terms of configuration of factors that cause positive and negative reactions [32]. Fuzzy convergence as a control of diversity in Ant Colony Optimization, a kind of population-based meta-heuristic that exploits a form of memory of past performance inspired by the real behavior of ants in foraging, with the aim of maintaining diversity at a certain level in order to avoid premature convergence created [33]. The following is explained in equation (1); where $\operatorname{Mt}(x)$ is a fuzzy value, $x$ is inputted as a fuzzy value, $x_{i}$ is the lower bound and $N$ is the upper limit.

$$
\operatorname{Mt}(x)=\left\{\begin{array}{l}
x-1,1 \leq x<N \\
1 \\
x_{i}, A<x \leq N
\end{array}\right.
$$

\subsection{Profile Matching}

Profile Matching (PM) is a decision making method assuming that decision making process considers a fulfilling of ideal value for predictor variable [34]. The decision maker should have an ideal value for each parameter operated to check all value of alternative decisions' parameter. The comparison between ideal and current value is going to produce gap value [35]-[36], like a distance of two parameters' value. Here, the marketing company has a standard value compared broadly with all aspects and then identify such a gap. The gap $(\delta)$ itself is measured by subtracting the profile of the marketer $(\mu)$ by the target value $(\tau)$.

After getting a gap value for each marketer profile, each profile is given a weight value by measuring the difference in weight values. The grading of weights can be determined as follows; if the difference is 0 then the weight value is 5 , if the difference is 1 then the weight value is 4.5 , if the difference is -1 then the weight value is 4 , if the difference is 2 then the weight value is 3.5 , if the difference is -2 then the weight value is 3 , if the difference is 3 then the weighted value is 2.5 , if the difference is -3 then the weighted value is 2 , if the difference is 4 then the weighted value is 1.5 and furthermore if the difference is -4 then the weighted value is 1 [35].

After determining the gap value in the difference between marketing profile and target value, then dividing aspects into two groups, namely core factor $(C F)$ and secondary factor $(S F)$, is done. $C F$ is a major factor in determining the criteria factors in the assessment process that can produce optimal performance as in equation (2); with $N C F$ as the average value of $C F, N C(a, n)$ as the total number 
of $C F$ and $I C$ values as the number of $C F$ items. Whereas $S F$ itself is a secondary factor apart from factors in the main criteria [37], can be calculated through equation (3); with NSF as the average value of $S F, N S(a, n)$ as the total number of $S F$ values and $I S$ as the number of $I S$ items.

$$
\begin{aligned}
& N C F=\frac{\sum N C(a, n)}{I C} \\
& N S F=\frac{\sum N S(a, n)}{I S}
\end{aligned}
$$

Calculation of the total value is obtained based on the calculation of $\mathrm{CF}$ and $\mathrm{SF}$ value calculations in determining the ranking of each marketing. The total value is the ranking of each marketing in a particular position [37]. Examples of calculations can be seen in the formula equation $(4)$; where $(a, n)$ is the marketing profile and target value, $N(a, n)$ is the total value of the aspect, $N C F(a, n)$ is the average value of $C F, \operatorname{NSF}(a, n)$ is the average value of $S F$ and $(x) \%$ is the percentage value inputted.

$$
N(a, n)=(x) \% N C F(a, n)+(x) \% N S F(a, n)
$$

\section{Research Methodology}

Based on the existing research framework, it is necessary to explain further about the stages of the research conducted. Where this stage starts from determining the objectives of the study, then finding the source of the existing problems, which is followed by conducting a literature study so that related parameters are obtained in dealing with the problems that occur. Then after that, the related parameters are analyzed further to further determine the appropriate method in handling the existing problems, until then carried out implementation and testing.

\subsection{Identification of Research Problems}

In medical appliance distributor companies, the problem that has been identified is related to the company's marketers. Where the motivation of the marketer itself is used as one of the sources in increasing company profits, one of which is by giving a commission. But technically the commission giving that is happening at the moment is still considered unsatisfactory because it tends to be an assessment carried out by the top-level subjective nature with the assumption that feelings tend to be more dominant so that social factors of jealousy often occur among fellow marketers. This has an impact on the decrease in motivation for some marketers who feel unacceptable to the existing assessment. For this reason, this research is conducted so that the research that takes place prioritizes the reality of the facts compared to the value of assumptions that have not been proven to be true.

\subsection{Literature Study}

Literature study is carried out to collect variables and problems that arise and the needs that are expected in determining top-marketers in the company. As this stage is carried out through a systematical literature review (SLR) to obtain relevant information in accordance with the research topic. SLR consists of identifying, evaluating and interpreting findings in research topics in order to answer predetermined research statements [38]. SLR was done by collecting related data through Sciencedirect literature library, with searches limited to the last 10 years. Where the title, abstract or keyword is also limited to the "decision support system" and marketing. Not only that, the data was also collected through Googlescholar library related to the data of the last five years with searches limited to only about multi-criteria DSM, so a number of data were obtained for analysis.

\subsection{Parameter Determination and Data Collection}

Henceforth the data obtained through the literature review stage are grouped again based on the objectives and research themes that have been determined. Through this, the influencing factors and related parameters are able to provide an initial picture of why this research is important to do. The data that has been collected correlatively, then also analyzes the factors that affect the performance or performance of marketers, until some parameters or criteria are identified that might affect the performance of each existing marketer.

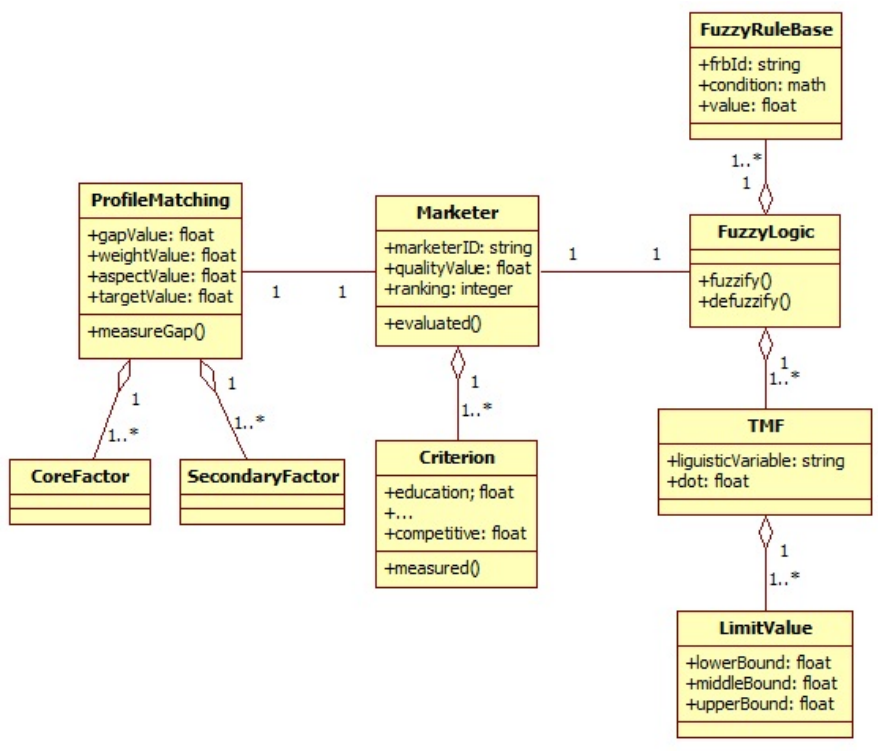

Figure 1: Class Diagram of Constructed Model

\subsection{Parameter Priority}

Based on the identification and collection of data that has been presented previously, it is necessary to analyze the data first. It is intended that problem solving can produce a solution, not a new problem. The decision support system using the PM and FL method is the right solution after an analysis of the problems often faced by one of the medical equipment distributor companies, so that the right decision can be generated easily based on available data.

Henceforth, the FL method with PM is a method that will be used as a solution to the existing problem, with FL functioning as the initial process in defining large amounts of data so that a mathematical definition is obtained which will be used as input to the PM method. Through the FL method linguistic terms defined 
membership function, where the membership function has a membership interval value from 0 to 1 . In order to solve the problem is able to produce the expected solution, the PM method is used as a right solution after FL analysis is done to obtain a ranking value so that it is easily determined top-marketer in medical equipment distributors.

\section{Result and Discussion}

\subsection{Proposed Model}

\subsubsection{High Level Configuration of Constructed Model}

The constructed model clearly depicted via class diagram in Figure 1. Mainly, it consists of three type of central classes: Marketer, FuzzyLogic, and ProfileMatching. Class criterion describes parameters considered in the model. Here, interconnections among parameters are described obviously. They operated to measure the quality and ranking of each marketer. All seventeen selected parameters are input of fuzzy rules and ranking is an output of fuzzy rules. The membership function used in the model is triangular membership function (TMF) with specific linguistic variables and limit value.

\subsubsection{Selected Parameters/Criterion}

Fuzzy values are formulated to help support the decision value by declaring right or wrong as an absolute input in the PM method to eliminate the value of ambiguity. FL is implemented on the marketing criteria attribute as shown in Table 1, so that the relevant values obtained as input to the PM method are obtained.

For the fuzzy membership value, the Education criteria are configured in Figure 2, where the level of member $(X)$ that intersects the axis $(Y)$ is divided into several level categories namely; Diploma, Bachelor, and Master with each fuzzy value $(1,1,2),(1,2,3)$, and $(2,3,3)$. For the pair of measurement criteria 1 , there are three levels of Goodness as shown in Figure 3. Where each level of membership $(X)$ which intersects the axis $(Y)$ is divided as follows; Not Good $(N G)$, Good $(G)$, and Very Good $(V G)$ with each fuzzy value; i.e. $(1,1,2),(1,2,3)$, and $(2,3,3)$. The fuzzy rules for Education VS Goodness criteria are then made as in Algorithm 1.

\begin{tabular}{l}
\hline Algorithm 1: Fuzzy Rules for Education VS Goodness \\
\hline Result: Goodness value \\
if (Edu is Diploma) then \\
else Goodness is NG; \\
end \\
end
\end{tabular}

\subsubsection{Process of Fuzzy Logic - Profile Matching}

Calculation of the value of the selected object gap has different calculation values [44]. Where the processing of raw data is carried out as follows; for marketers with parameter P01, the value of the raw data entered refers as in Figure 1 with diploma education level having a value of 1 , bachelor education level having a value of 2 and master education level having a value of 3 .

For parameter $\mathrm{P} 02$, value input refers to the number of customers handled by each marketer. For example, Marketer M01 handles two customers who are in the presence, the raw data input value is 2 . As for the parameter P03, the input value is based on the current billing amount. Where if there is 1 smooth customer bill, the value is 1 and for 1 non-current, worth -1 . Then the next value is added up as raw data input.

For the parameter P04, the input value of raw data is obtained based on the accumulation of the number of machines that can be installed on each customer. For example, Marketer M01 the number of machines installed on the customer he has is 4, the raw data input value is 4.Then for the parameter P05 input value, the value is inputted based on the service class owned by the marketer. For example, Marketer M01 service class service is 1, then the value of raw data input is also worth 1. Furthermore, for the value of parameter P06 input, inputted based on the amount of reduction in the machine to the customer owned by each marketer. Missal marketer M01 has 1 engine reduction in the customer he has, so the value of raw data input is 1 .

Followed by the parameter P07, the input of raw data is accumulated based on the year of joining the company. For example, marketer M01 started to join the company in 2018, so based on the current year (2019), the marketer has only joined the company for 1 year. So the raw data input value is 1 . Furthermore, for parameter P08, raw data input is obtained based on the average value of customer actions owned by each marketer. If the marketer M01 has an average value of customer actions of 15 , the raw data input value is also 15. Then the parameter P09 input value is based on the consistency value of the promise fill. If the Marketer M01 has the consistency value of promise filling is 0 , then the raw data input is also worth 0 . And for the parameter P10, if the percentage value of achieving the Marketer M01 target is $60 \%$, the raw data input value is also worth 60 .

Then for the parameter P11, input is based on the number of additional machines that can be done by marketers. If the addition of machines installed by Marketer M01 amounts to 0 , then the value of inputting raw data is also worth 0 . For the input of the P12 criterion is based on the average achievement of visits to the number of customers handled. If the marketer M01, the visit is 0 , the raw data input value is also 0 . And for the parameter P13, based on the level of productivity. If the Marketer M01 has a productivity value of 0 , the raw data input is also 0 .

For parameter P14 itself, raw value input is based on the number of HD products that can be sold in each month. For example, a Marketer M01 is able to sell $120 \mathrm{HD}$ products, so the raw data input value is also 120. As for the Marketer M01's P15, the value of raw data input is based on the amount of cooperation that can be built by the relevant marketer. If Marketer M01 does not get a cooperative relationship with any customer, then the raw data input value is 0 . 
Table 1: Selected Parameters

\begin{tabular}{|c|c|c|}
\hline Code & Parameter & Reference \\
\hline P01 & Education & [39] \\
\hline $\mathrm{P} 02$ & Verbalization idea & {$[\overline{39} \mid[40 \mid[\overline{41]}$} \\
\hline P03 & Reasoning and real solution & [39] \\
\hline P04 & Concentration & [39][40][41][42] \\
\hline P05 & Creativity of imagination & [39] \\
\hline P06 & Anticipation & [39] \\
\hline P07 & Years of service & [39][43] \\
\hline P08 & Accuracy and responsibility & [39] \\
\hline P09 & Behaviour & [39] \\
\hline P10 & Work achievement & {$[39][40][43]$} \\
\hline P11 & Vitality and planer & [39][40][41] \\
\hline P12 & Discipline & [39] \\
\hline P13 & Attitude toward company & {$[40$} \\
\hline P14 & Quantity of work & [40] \\
\hline P15 & Work setting & [40][41] \\
\hline P16 & Reliable & 40 \\
\hline P17 & Competitive & [41] \\
\hline
\end{tabular}

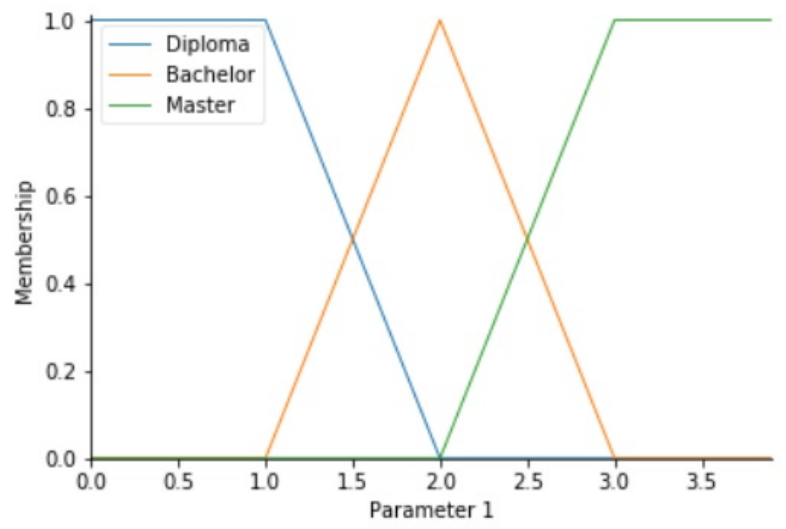

Figure 2: Membership Functions for Parameter 1

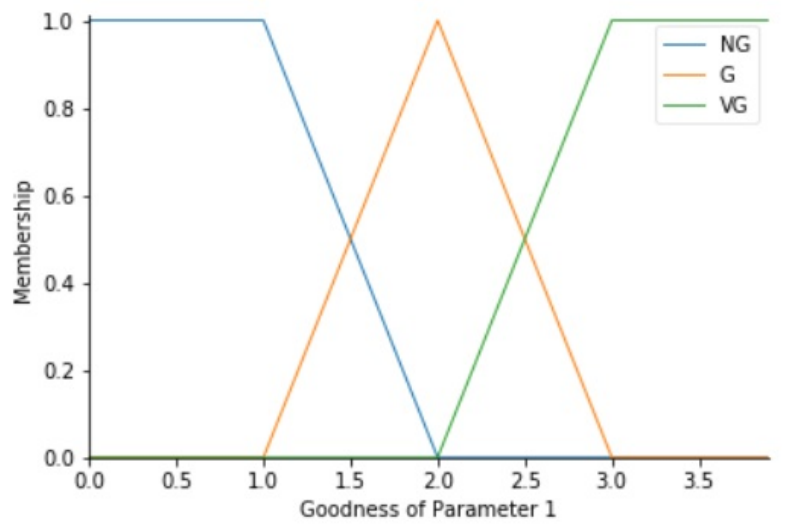

Figure 3: Membership Function for Goodness of Parameter 1

Then for parameter P16, raw data input is based on the number of new HD Center additions. If the Marketer M01 cannot get the addition of a new HD Center, then the raw data input value is 0 .
And finally for the parameter P17, the raw data input value is based on the marketer's ability to reduce the number of machines installed at the customers they have. For example, Marketer M01 cannot reduce the number of competitor machines installed on the customer he is handling, so the raw data input value is 0 . Likewise for raw data input on other marketers, the data input process is the same as inputting the Marketer M01's raw data.

Next we can see in Table 2, an example of the data of 21 marketers that we will use as a sample calculation of FL and PM values. The processing of raw data from each marketer is presented hereinafter to be inputted to FL which then produces output which will be inputted to the PM method.

Table 2: Sample Data of Marketers

\begin{tabular}{|c|c|c|c|c|c|}
\hline Marketer & P01 & P02 & $\ldots$ & P16 & P17 \\
\hline M01 & 2 & 2 & $\ldots$ & 0 & 0 \\
\hline M02 & 2 & 4 & $\ldots$ & 0 & 0 \\
\hline$\ldots$ & $\ldots$ & $\ldots$ & $\ldots$ & $\ldots$ & $\ldots$ \\
\hline M20 & 2 & 2 & $\ldots$ & 0 & 0 \\
\hline M21 & 2 & 10 & $\ldots$ & 0 & 0 \\
\hline
\end{tabular}

The first step is to determine the polar interpolation of this value, then proceed to determine the center of gravity with the following formula. Equation (5) is a formula for determining linear interpolation of marketer criteria. Also equation (6) is a formula for determining Central of Gravity $(\mathrm{CoG})$ on marketer's criteria.

$$
\begin{gathered}
Y=Y 0+(X-X 0) \frac{Y 1-Y 0}{X 1-X 0} \\
C o G=\frac{\sum(\text { Fot })(\text { FGrade })}{\sum(\text { Fot })}
\end{gathered}
$$

We see fuzzy calculations for the Education criteria for Marketers with the M01 code. Numeric values in the basic rules will be processed to get the value of $Y(S 1)$. Through the description of Figure 1 we get the input for $Y 0$ is $1, Y 1$ is $0, X$ is $2, X 0$ is 2 and $X 1$ is 3 , so after being entered into equation (5) following $Y(S 1)=1+(2-2)(0-1) /(3-2)$ the result is 1 . After the Education criteria interpolation results are obtained, then adjusted to rules 1 and adjust fuzzy interpolation input with Table 3, ElS EIF Edu is 1 THEN Goodness is 1 . Then the CoG value is determined according to equation $(6), C o G=((1 * 3)+(1 * 3)) /(1+1)$ so that the value obtained is 3 .

Next we look at fuzzy calculations for the Verbalization Idea criteria on Marketers with the M01 code. Numeric values in the basic rules will be processed to get the value $Y(K)$. Through the description of Figure 3 we get the input for $Y 0$ is $1, Y 1$ is worth $1, X$ is worth $2, X 0$ is worth 5 , and $X 1$ is worth 10 , so after it is entered into equation (5) following $Y(K)=1+(2-5)(1-1) /(10-5)$ the result is 1 .

After interpolation results obtained by the Verbalization Idea criteria, then adjusted to AF 02 rules and adjusting fuzzy interpolation input with Table 3, IF (VI is 1) THEN Goodness is 1. Then the $C o G$ value is determined according to equation (6), CoG $=((1 * 1)+(1 * 1)) /(1+1)$ so that the value obtained is 1 . Henceforth we do the same steps in the sample data Table 2. by following the calculation method of P1 and P2 on Marketer M01. 
After the calculation is done for all criteria and marketers, the overall results can be seen in Table 3 .

Table 3: Result of FL Process

\begin{tabular}{|c|c|c|c|c|c|}
\hline Marketer & P01 & P02 & $\ldots$ & P16 & P17 \\
\hline M01 & 3.0 & 1.0 & $\ldots$ & 1.0 & 1.0 \\
\hline M02 & 3.0 & 1.0 & $\ldots$ & 1.0 & 1.0 \\
\hline$\ldots$ & $\ldots$ & $\ldots$ & $\ldots$ & $\ldots$ & $\ldots$ \\
\hline M20 & 3.0 & 1.0 & $\ldots$ & 1.0 & 1.0 \\
\hline M21 & 3.0 & 3.0 & $\ldots$ & 1.0 & 1.0 \\
\hline
\end{tabular}

\subsection{The Result Applied to Medical Company}

After the fuzzy value is determined, the next aspect is divided into two groups, Core Factor $(C F)$ and Secondary Factor $(S F)$ as in Table 4. $C F$ is the main factor in determining the assessment process that can produce optimal performance, while $S F$ is a secondary or supporting factor in addition to factors in the main criteria [36]-[37].

Table 4: Assessment Aspects

\begin{tabular}{|l|l|}
\hline Core Factor & Secondary Factor \\
\hline Accuracy and responsibility & Work achievement \\
\hline & Education \\
\hline & Concentration \\
\hline & Quantity of work \\
\hline & Reliable \\
\hline Verbalization idea & Reasoning and real solution \\
\hline & Creativity of imagination \\
\hline & Anticipation \\
\hline & Vitality and planner \\
\hline Attitude toward company & Competitive \\
\hline & Years of service \\
\hline & Behaviour \\
\hline & Discipline \\
\hline & Work setting \\
\hline
\end{tabular}

Table 5: Calculation of GAP Value for Each Parameter

\begin{tabular}{|c|r|r|r|r|r|}
\hline Marketer & P01 & P02 & $\ldots$ & P16 & P17 \\
\hline M01 & 3.0 & 1.0 & $\ldots$ & 1.0 & 1.0 \\
\hline M02 & 3.0 & 1.0 & $\ldots$ & 1.0 & 1.0 \\
\hline$\ldots$ & $\ldots$ & $\ldots$ & $\ldots$ & $\ldots$ & $\ldots$ \\
\hline M20 & 3.0 & 1.0 & $\ldots$ & 1.0 & 1.0 \\
\hline M21 & 3.0 & 3.0 & $\ldots$ & 1.0 & 1.0 \\
\hline & & & & & \\
\hline GAP & 3.0 & 3.0 & $\ldots$ & 3.0 & 3.0 \\
\hline & & & & & \\
\hline M01 & 0.0 & -2.0 & $\ldots$ & -2.0 & -2.0 \\
\hline M02 & 0.0 & -2.0 & $\ldots$ & -2.0 & -2.0 \\
\hline$\ldots$ & $\ldots$ & $\ldots$ & $\ldots$ & $\ldots$ & $\ldots$ \\
\hline M20 & 0.0 & -2.0 & $\ldots$ & -2.0 & -2.0 \\
\hline M21 & 0.0 & 0.0 & $\ldots$ & -2.0 & -2.0 \\
\hline
\end{tabular}

After classifying $C F$ and $S F$, the next step is to determine the gap value for each criterion based on equation (2). Where we can see an example of determining the Gap value for M01 marketers in the Education criteria column, 3 minus the gap value 3 (the standard ideal value in the Education criteria) the result is 0 . With the overall marketer's results can be seen in Table 5. After the gap value is obtained, the weight value is determined based on the provisions in Table 1. With each employee there is a weight value table [44], which looks like in Table 6. After the difference results are obtained, each aspect is grouped into 2 groups, namely by determining the value of $C F$ and $S F$ [44]. How to calculate the average value according to equation (3) and equation (4) so that the results obtained are as in Table 7 and Table 8.

Table 6: Weight for each Parameter

\begin{tabular}{|c|c|c|c|c|c|}
\hline Marketer & P01 & P02 & $\ldots$ & P16 & P17 \\
\hline M01 & 5.0 & 3.5 & $\ldots$ & 3.5 & 3.5 \\
\hline M02 & 5.0 & 3.5 & $\ldots$ & 3.5 & 3.5 \\
\hline$\ldots$ & $\ldots$ & $\ldots$ & $\ldots$ & $\ldots$ & $\ldots$ \\
\hline M20 & 5.0 & 3.5 & $\ldots$ & 3.5 & 3.5 \\
\hline M21 & 5.0 & 0.0 & $\ldots$ & 3.5 & 3.5 \\
\hline
\end{tabular}

Table 7: CF Value

\begin{tabular}{|c|c|c|c|c|}
\hline Marketer & VI & AR & Atc & CF \\
\hline M01 & 3.50 & 2.00 & 3.50 & 3.00 \\
\hline M02 & 3.50 & 4.00 & 3.50 & 3.67 \\
\hline$\ldots$ & $\ldots$ & $\ldots$ & $\ldots$ & $\ldots$ \\
\hline M20 & 3.50 & 1.00 & 3.50 & 2.67 \\
\hline M21 & 0.00 & 3.50 & 3.50 & 1.75 \\
\hline
\end{tabular}

Table 8: SF Value

\begin{tabular}{|c|c|c|c|c|c|c|}
\hline Marketer & P01 & P02 & $\ldots$ & P16 & P17 & SF \\
\hline M01 & 5.0 & 3.5 & $\ldots$ & 3.5 & 3.5 & 3.25 \\
\hline M02 & 5.0 & 3.5 & $\ldots$ & 3.5 & 3.5 & 2.64 \\
\hline$\ldots$ & $\ldots$ & $\ldots$ & $\ldots$ & $\ldots$ & $\ldots$ & $\ldots$ \\
\hline M20 & 5.0 & 3.5 & $\ldots$ & 3.5 & 3.5 & 2.79 \\
\hline M21 & 5.0 & 0.0 & $\ldots$ & 3.5 & 3.5 & 3.29 \\
\hline
\end{tabular}

Table 9: Ranking for each Marketer

\begin{tabular}{|c|c|c|c|c|}
\hline Marketer & CF & SF & N (a, n) & Ranking \\
\hline M01 & 3.00 & 3.25 & 3.10 & 5 \\
\hline M02 & 3.67 & 2.64 & 3.26 & 4 \\
\hline M03 & 0.17 & 3.15 & 1.36 & 21 \\
\hline$\ldots$ & $\ldots$ & $\ldots$ & $\ldots$ & $\ldots$ \\
\hline M09 & 3.67 & 3.61 & 3.65 & 1 \\
\hline$\ldots$ & $\ldots$ & $\ldots$ & $\ldots$ & $\ldots$ \\
\hline M20 & 2.67 & 2.79 & 2.72 & 8 \\
\hline M21 & 1.75 & 3.29 & 2.37 & 14 \\
\hline
\end{tabular}

Calculation of the total value of each marketer is obtained based on equation (5) with the percentage of $\mathrm{CF}$ is $65 \%$ and the percentage of SF is $45 \%$. The total value itself is a ranking of each marketer in 
a certain position [37], as shown in Table 9. In addition, for more details, we can see the value of marketer ranking through Figure 4. It can be seen on the graph that the highest value achieved by Marketer $M 09$ is ranked first with a ranking value of 3.65, while the lowest value can be seen obtained by Marketer M03 with a rating of 1.36. The result of marketer ranking is new idea to see marketer objectively. Then, the company can take a proper decision to give a reward.

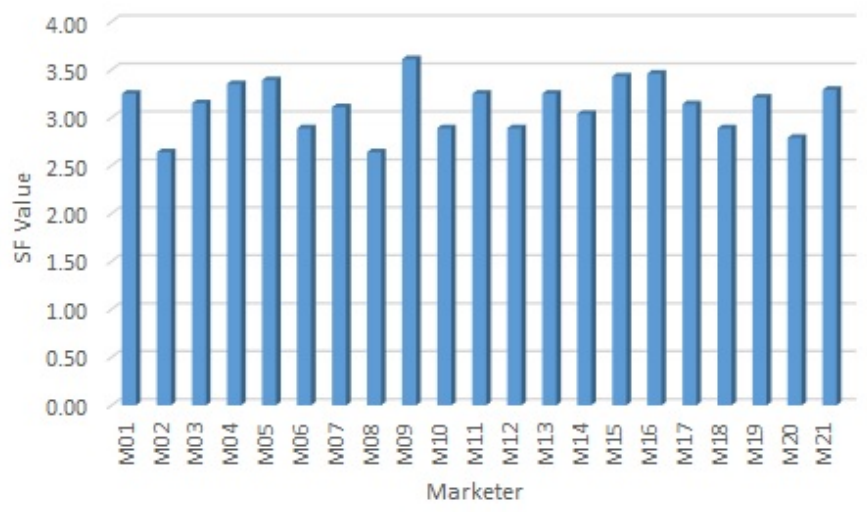

Figure 4: Marketers' SF Value Charts

\section{Conclusion and Furtherworks}

A generic DSM for determining the best marketer of particular medical equipment distributor company based on main methods FL and PM was methodically developed. Seventeen verified-selected parameters considered in the model; where they were scientifically adopted from five scientific manuscripts. The model is a novel model that is able to enrich the knowledge domain of computer science. Also, the study result can be functioned as a formal procedure in evaluating the employees' performance generally. Thus it contributes to the real world practically.

In addition, the application of FL and PM methods is very useful in determining the value of marketer ranking. Because the level of accuracy of the FL method is able to minimize the value of ambiguity, so the expected final results will be more accurate and rational. The model is very useful in helping top-level decision making. Because here the top-level is required to be more professional by putting aside feelings and assumptions in deciding something. Through the results of research that have been obtained, top-level companies where research is conducted can make decisions more quickly and effectively when determining who has the right to become a Top-Marketer of the company. So that with this also doubts can be minimized and can reduce mental burdens or mistakes that may be more dominated by the feeling element.

Finally, new parameters should be taken in to account for next study (e.g. communication skill, informal education, etc.). To do so, the deep literature study is possibly to conduct. And also, for implementing other methods is still open to conduct (e.g. optimization method, simple additive weighting, etc.). The proper and more detail methods implementation is able to make the model more reliable and fruitful scientifically.

\section{References}

[1] V. Chouliaras, A. Gazepis, T. Kargidis, "Marketing's Contribution to the Profitability of Greek Enterprises During the Economic Crisis" Procedia Economics and Finance, 19, 217-225, 2015. doi: 10.1016/S2212-5671(15)00023-4

[2] H. Lim, J. G. Choi, A. Akhmedov, J. Chung, "Predicting future trends of media elements in hotel marketing by using Change Propensity Analysis" International Journal of Hospitality Management, 278-431, 2018. doi: 10.1016/j.ijhm.2018.10.001

[3] F. Y. Lo, N. Campos, "Blending internet-of-things (IoT) solutions into relationship marketing strategies" Technological Forecasting and Social Change, 137, 10-18, 2018. doi: 10.1016/j.techfore.2018.09.029

[4] S. F. Slater, G. T. M. Hult, E. M. Olson, "Factors influencing the relative importance of marketing strategy creativity and marketing strategy implementation effectiveness" Industrial Marketing Management, 39(4), 551-559, 2010. doi: 10.1016/j.indmarman.2008.03.007

[5] J. Y. Ho, M. Dempsey, M. "Viral marketing: Motivations to forward online content" Journal of Business research, 63(9-10), 1000-1006, 2010. doi 10.1016/j.jbusres.2008.08.010

[6] A. Sela, D. Goldenberg, I. Ben-Gal, E. Shmueli, "Active viral marketing: Incorporating continuous active seeding efforts into the diffusion model" Expert Systems with Applications, 107, 45-60, 2018. doi: 10.1016/j.eswa.2018.04.016

[7] J. Tian, Y. Zhang, C. Zhang, "Predicting consumer variety-seeking through weather data analytics" Electronic Commerce Research and Applications, 28, 194-207, 2018. doi: 10.1016/j.elerap.2018.02.001

[8] G. Bykzkan, B. Ergn, "Intelligent system applications in electronic tourism" Expert systems with applications, 38(6), 6586-6598, 2011. doi: 10.1016/j.eswa.2010.11.080

[9] T. Turk, O. Kitapci, I. T. Dortyol, "The usage of geographical information systems (GIS) in the marketing decision making process: a case study for determining supermarket locations" Procedia-Social and Behavioral Sciences, 148, 227-235, 2014. doi: 10.1016/j.sbspro.2014.07.038

[10] M. Moradi, A. Aghaie, M. Hosseini, "Knowledge-collector agents: Applying intelligent agents in marketing decisions with knowledge management approach" Knowledge-Based Systems, 52, 181-193, 2013. doi: 10.1016/j.knosys.2013.08.014

[11] C. Kiss, M. Bichler, "Identification of influencersmeasuring influence in customer networks" Decision Support Systems, 46(1), 233-253, 2008. doi 10.1016/j.dss.2008.06.007

[12] S. L. France, M. S., Vaghefi, H. Zhao, "Characterizing viral videos: Methodology and applications" Electronic Commerce Research and Applications, 19, 19-32, 2016. doi: 10.1016/j.elerap.2016.07.002

[13] M. Ripolls, A. Blesa, "International new ventures as small multinationals: The importance of marketing capabilities" Journal of World Business, 47(2), 277-287, 2012. doi: 10.1016/j.jwb.2011.04.015

[14] L. Khiali, D. Ienco, M. Teisseire, "Object-oriented satellite image time series analysis using a graph-based representation" Ecological informatics, 43, 52-64 2018. doi: 10.1016/j.ecoinf.2017.11.003

[15] D. N. Utama, Sistem Penunjang Keputusan: Filosofi, Teori, dan Implementasi Garudhawaca, 2017.

[16] F. Gunawan, G. Wang, D. N. Utama, S. Komsiyah, "Decision Support Model for Supplier Selection Using Fuzzy Logic Concept" in International Conference on Information Management and Technology, 394-399, 2018. doi: 10.1109/ICIMTech.2018.8528103

[17] L. A. Zadeh, "Fuzzy logica personal perspective" Fuzzy sets and systems, 281, 4-20, 2015. doi: 10.1016/j.fss.2015.05.009

[18] D. N. Utama, E. Rustamaji, "Fuzzy Decision Support Model for Human Resources Performance Appraisal" Proceedings of 2018 International Conference on Information Management and Technology, 272-276, 2018. doi: 10.1109/ICIMTech.2018.8528145 
[19] J. W. Liu, "Using big data database to construct new GFuzzy text mining and decision algorithm for targeting and classifying customers" Computers \& Industrial Engineering, 2018. doi: 10.1016/j.cie.2018.04.003

[20] Q. Zhou, Z. Xu, N. Y. Yen, "User sentiment analysis based on social network information and its application in consumer reconstruction intention" Computers in Human Behavior, 100, 177-183, 2018. doi: 10.1016/j.chb.2018.07.006

[21] A. Vafadarnikjoo, N. Mishra, K. Govindan, K. Chalvatzis, "Assessment of Consumers' Motivations to Purchase a Remanufactured Product by Applying Fuzzy Delphi Method and Single Valued Neutrosophic Sets" Journal of Cleaner Production, 196, 230-244, 2018. doi: 10.1016/j.jclepro.2018.06.037

[22] K. Howells, A. Ertugan, "Applying fuzzy logic for sentiment analysis of social media network data in marketing" Procedia computer science, 120, 664-670, 2017. doi: 10.1016/j.procs.2017.11.293

[23] D. N. Utama, U. Taryana, "Fuzzy Logic For Simply Prioritizing Information In Academic Information System" International Journal of Mechanical Engineering and Technology (IJMET), 10(2), 1594-1602 2019.

[24] L. Suganthi, S. Iniyan, A. A. Samuel, "Applications of fuzzy logic in renewable energy systemsa review" Renewable and sustainable energy reviews, 48, 585-607, 2015. doi: 10.1016/j.rser.2015.04.037

[25] A. Ford, J. M. Miller, A. G. Mol, "A comparative analysis of weights of evidence, evidential belief functions, and fuzzy logic for mineral potential mapping using incomplete data at the scale of investigation" Natural Resources Research, 25(1), 19-33, 2016.

[26] O. Castillo, L. Amador-Angulo, J. R. Castro, M. Garcia-Valdez, "A comparative study of type- 1 fuzzy logic systems, interval type-2 fuzzy logic systems and generalized type-2 fuzzy logic systems in control problems" Information Sciences, 354, 257-274, 2016. doi: 10.1016/j.ins.2016.03.026

[27] S. Vaidyanathan, A. T. Azar, "Takagi-Sugeno fuzzy logic controller for LiuChen four-scroll chaotic system" International Journal of Intelligent Engineering Informatics, 4(2), 135-150, 2016. doi: 10.1504/IJIEI.2016.076699

[28] D. Arcos-Aviles, J. Pascual, L. Marroyo, P. Sanchis, F. Guinjoan, "Fuzzy logic-based energy management system design for residential grid-connected microgrids" IEEE Transactions on Smart Grid, 9(2), 530-543, 2016. doi: 10.1109/TSG.2016.2555245

[29] A. Ali, L. Abbas, M. Shafiq, A. K. Bashir, M. K. Afzal, H. B. Liaqat, ..., K. S Kwak, "Hybrid fuzzy logic scheme for efficient channel utilization in cognitive radio networks" IEEE Access, 7, 24463-24476, 2019. doi: 10.1109/ACCESS.2019.2900233

[30] R. Logambigai, A. Kannan, "Fuzzy logic based unequal clustering for wireless sensor networks" Wireless Networks, 22(3), 945-957, 2016.

[31] E. Rodrguez, R. Peche, C. Garbisu, I. Gorostiza, L. Epelde, U. Artetxe, ..., J. Etxebarria, "Dynamic Quality Index for agricultural soils based on fuzzy logic" Ecological indicators, 60, 678-692, 2016. doi: 10.1016/j.ecolind.2015.08.016
[32] J. T. Campbell, D. G. Sirmon, M. Schijven, "Fuzzy logic and the market: A configurational approach to investor perceptions of acquisition announcements" Academy of Management Journal, 59(1), 163-187, 2016. doi: 10.5465/amj.2013.0663

[33] O. Castillo, H. Neyoy, J. Soria, P. Melin, F. Valdez, "A new approach for dynamic fuzzy logic parameter tuning in ant colony optimization and its application in fuzzy control of a mobile robot" Applied soft computing, 28, 150-159, 2015. doi: 10.1016/j.asoc.2014.12.002

[34] J. Fitriana, E. F. Ripanti, Tursina, "Sistem Pendukung Keputusan Pemilihan Mahasiswa Berprestasi denga Metode Profile Matching (Studi Kasus: Fakultas Teknik UNTAN)" Jurnal Sistem dan Teknologi Informasi, 6(4), 153-160, 2018.

[35] S. Oktafiani, D. N. Utama, "Generic Model of Fuzzy Profile Matching for Determining the Best Marketer" International Journal of Advanced Trends in Computer Science and Engineering, 9(1), 859-869, 2020. doi: $10.30534 /$ ijatcse/2020/123912020

[36] A. Verdian, A. Wantoro, "Komparasi Metode Profile Matching Dengan Fuzzy Profile Matching Pada Pemilihan Wakil Kepala Sekolah" Jurnal Ilmiah Media Sisfo, 13(2), 97-105, 2019.

[37] L. Sopianti, N. Bahtiar, "Student Major Determination Decision Support Systems using Profile Matching Method with SMS Gateway Implementation" Jurnal Sains dan Matematika, 23(1), 14-24, 2015.

[38] R. B. Gandara, G. Wang, D. N. Utama, "Hybrid Cryptography on Wireless Sensor Network: A Systematic Literature Review" in 2018 International Conference on Information Management and Technology, 2018. doi: 10.1109/ICIMTech.2018.8528147

[39] A. A. T. Susilo, "Penerapan Metode Profile Matching pada Sistem Pendukung Keputusan Pemilihan Ketua Program Studi (STUDI Kasus: Program Studi Teknik Informatika STMIK Musi Rawas)” JUITA: Jurnal Informatika, 5(2), 87-93, 2018.

[40] R. Nasriyah, Z. Arham, Q. Aini, "Profile matching and competency based human resources management approaches for employee placement decision support system (case study)”, Asian J. Appl. Sci, 9(2), 75-86, 2016. doi: 10.3923/ajaps.2016.75.86

[41] T. Susilo, A. Anto, "Penerapan Metode Composite Performance Index (CPI) pada Pemilihan Hotel di Kota Lubuklinggau" Jurnal Rekayasa Sistem dan Teknologi Informasi, 1(3), 204-210, 2017.

[42] B. W. Sari, "Perbandingan Metode Profile Matching Dan Simple Additive Weighting Pada Penentuan Jurusan Siswa Kelas X SMA N 2 Ngaglik" Data Manajemen dan Teknologi Informasi (DASI), 16(1), 2015.

[43] A. Nurdianto, S. J. Hartati., Y. M. Maulana, "Rancang Bangun Sistem Pendukung Keputusan Penempatan Tenaga Pendidik Menggunakan Metode Profile Matching” Jurnal Sistem informasi dan Komputer Akuntansi, 5(2), 1-8, 2016.

[44] T. Susilowati, E. Y. Anggraeni, W. Andewi, Y. Handayani, A. Maseleno, "Using Profile Matching Method to Employee Position Movement" Int. J. Pure Appl. Math, 118(7), 415-423, 2018. 